\title{
Tantangan Mendidik Anak-Anak Pendeta di Gereja Masehi Advent Hari Ketujuh (GMAHK) DKI Jakarta Melalui Penerapan Disiplin dan Keteladanan
}

\author{
Aby Gayel \\ Universitas Advent Indonesia \\ Email: abi.sihombing@gmail.com \\ Stimson Hutagalung \\ Universitas Advent Indonesia \\ Email: stimson.hutagalung@unai.edu \\ Rolyana Ferinia \\ Universitas Advent Indonesia \\ Email: rolyana.pentauli@unai.edu
}

\begin{abstract}
The purpose of this study is to obtain a description concerning the application of the right discipline influences and the pastor's role model towards the faithfulness of the pastor's children to God. This study uses the descriptive method by giving a questionnaire to the pastor's children whose parents serve as the pastor at the Jakarta Local Conference Seventh Day Adventist Church with 108 samples of pastor's children aged from 15 years old randomly determined. The results show that most of the pastor's children had a good perception of the application of the right discipline that must be started early and the role model of the pastors towards the faithfulness of pastor's children to God. The expected implication is that the pastor and his whole family can be a good example for the church community in particular so as not to be a bad impact on the spiritual growth of the congregation.
\end{abstract}

Keywords: Discipline, Exemplary, Faithfulness, Pastor's Children

\begin{abstract}
Abstrak
Tujuan dari penelitian ini adalah untuk mendapatkan deskripsi tentang penerapan disiplin yang benar dan peran keteladanan pendeta terhadap kesetiaan anak-anak pendeta kepada Tuhan. Penelitian ini menggunakan metode deskriptif dengan memberikan angket kepada anak-anak pendeta dimana orang tua mereka melayani di Gereja Masehi Advent Hari Ketujuh (GMAHK) Konfrens DKI Jakarta dengan sampel 108 orang anak-anak pendeta dengan usia 15 tahun keatas yang ditentukan secara acak. Hasil penelitian menunjukkan bahwa sebagian besar anak pendeta memiliki persepsi yang baik mengenai penerapan disiplin yang benar yang harus dimulai sejak dini, dan bahwa pendeta harus menunjukan keteladanan melalui pola hidup bukan hanya melalui pengajaran, sehingga melalui penerapan disiplin yang benar dan peran keteladanan seorang pendeta akan mempengaruhi peningkatan kesetiaan anak-anak pendeta kapada Tuhan. Implikasi yang diharapkan adalah agar pendeta dan seluruh
\end{abstract}


keluarganya dapat menjadi teladan yang baik bagi masyarakat gereja secara khusus agar tidak menjadi dampak buruk bagi pertumbuhan kerohanian jemaat.

\section{Kata kunci: Disiplin, Keteladanan, Kesetiaan, Anak Pendeta}

\section{PENDAHULUAN}

Pekerjaan seorang imam dalam Perjanjian Lama adalah pekerjaan yang sangat tinggi derajatnya di tengah-tengah bangsa Israel (Simamora \& Panjaitan, 2018), Tuhanlah yang telah memilih orangorang-Nya dalam pekerjaan keimamatan ini. Salah satu imam yang sangat dihormati pada saat itu adalah imam Eli, White menyatakan bahwa imam Eli adalah orang yang suci yang ditetapkan di seluruh negri itu sebagai satu teladan. Ia memberikan pengaruh besar terhadap bangsa itu. Sekalipun Ia telah ditetapkan untuk memerintah bangsa Israel dan sebagai imam dan hakim, tetapi Ia telah gagal saat memerintah keluarganya dengan baik (White, 2011). Dalam 1 Samuel 2 mulai dari ayat 11 Alkitab menceritakan kejahatan dari anak-anak imam Eli. Di catat bahwa anak-anak lelaki imam Eli adalah orang-orang yang dursila, dan mereka tidak mengindahkan Tuhan. Ketika menjalankan tugas untuk mempersembahkan korban sembelihan kepada Tuhan mereka tidak melakukannya dengan benar sesuai perintah Tuhan. Dalam hal ini anakanak Imam Eli hanya fokus untuk memenuhi nafsu kedagingan mereka dibandingkan melakukan tugas mengantarai umat Israel dengan Tuhan. Lebih menyedihkan lagi bahkan dalam pasal tersebut dikatakan anak-anak imam Eli tidur dengan perempuan-perempuan yang melayani di depan pintu Kemah Pertemuan. Sebagai anak seorang imam yang juga sudah melayani sebagai seorang imam seharusnya mereka menguduskan diri dan menjauhi prilaku dursila.

Dalam kisah ini ternyata Allah menegur Imam Eli sebagai orang tua mereka, Alkitab mencatat dalam 1 Samuel 2: 29 "Mengapa engkau memandang dengan loba kepada korban sembelihan-Ku dan korban sajian-Ku, yang telah Kuperintahkan, dan mengapa engkau menghormati anak-anakmu lebih dari pada-Ku, sambil kamu menggemukkan dirimu dengan bagian yang terbaik dari setiap korban sajian umat-Ku Israel?". Disini Allah bukan hanya mempersalahkan Hofni dan Pinehas tetapi juga orang tua mereka yaitu imam Eli. Imam Eli tidak memberikan contoh teladan yang baik bagi kedua anak mereka dalam mempersembahkan korban bakaran. Imam Eli juga lebih menghormati anak-anaknya dari pada menghormati Tuhan. Imam Eli memanjakan anaknya dan membiarkan mereka berprilaku sewenang-wenang. Dari 
uraian di atas, penulis mencoba melihat 1). disiplin seperti apa yang terjadi di zaman ini di kalangan anak-anak pendeta yang sudah remaja dan dewasa? 2). Penerapan keteladanan seperti apa yang orang tua berikan kepada anaknya?

Sama seperti anak imam Eli demikian juga dengan anak pendeta, mereka selalu menjadi sorotan. Orang akan berharap banyak agar anak pendeta menjadi teladan di tengah-tengah masyarakat gereja. Anak-anak pendeta punya tantangan tersendiri dalam menjalani hidupnya. Oliver, (2017) menjelaskan sebuah fenomena yang mengatakan bahwa anak pendeta memiliki reputasi yang buruk. Murrel, (2019) juga mengakui di tengah-tengah lingkungannya banyak anak-anak pendeta yang bertingkah liar dan sangat duniawi. Anak-anak pendeta ini bahkan mengajak yang bukan anak pendeta untuk melakukan tindakantindakan melanggar aturan. Murrell mengakui bahwa keadaan ini bukan lagi menjadi hal yang baru di lingkungannya melainkan sudah sering kali didapati disekitarnya anak-anak pendeta yang tidak setia kepada Tuhan (Murrel, 2019).

Sehubungan dengan kenakalan yang terjadi dikalangan anak-anak pendeta, Barna Group membuat suatu penelitian yang datang dari 603 pendeta yang memiliki anak usia di atas 15 tahun. Hasil penelitian tersebut mengatakan bahwa $40 \%$ dari antara mereka masuk ke dalam fase meragukan iman mereka. 33\% tidak lagi aktif di dalam kegiatan perbaktian di gereja, 7\% bahkan tidak lagi menganggap diri mereka Kristen (Soesilo, 2014). Sebagaimana kasus yang terjadi pada imam Eli, anak-anak imam tidak mendapat disiplin tegas dari ayahnya itulah salah satunya penyebab mereka melakukan tindakan pemberontakan (Soesilo, 2014). Demikian juga yang terjadi kepada anak pendeta saat ini. Kenakalan anak pendeta semakin merajaleka karena akses teknologi melalui media yang sangat sulit untuk di kontrol (Oliver, 2017). Oleh karena itu keteladanan pendeta sebagai orang tua adalah hal yang sangat penting. Pendeta harus menunjukan kesetiaannya dihadapan anak-anaknya (Borrong, 2015). Anak pendeta benar-benar mengalami berbagai kesulitan dalam mencari identitas diri karena tekanan dari sekitar mereka. Dampaknya kepada spiritualitas pribadi mereka dalam arti mengenal Yesus sebagai Tuhan dan Juruselamat (Soetopo, 2015).

Dari pandangan inilah didapati bahwa fenomena kenakalan yang terjadi di kalangan anak pendeta benar adanya. Sebagaimana yang terjadi kepada anakanak Imam Eli dan anak-anak Samuel, fenomena ini pun terjadi di kalangan anakanak pendeta saat ini. Tidak bisa dipungkiri kita mendapati anak-anak hamba Tuhan bermasalah (Chen, 2015). 
Pendeta adalah seorang yang matang dalam imannya. Pendeta dan keluarganya harus menjadi panutan dihadapan jemaat dalam hal apapun. Mereka adalah orangorang yang dijunjung tinggi di dalam jemaat. Keluarga pendeta khususnya anak pendeta hidup selayaknya di rumah kaca sehingga sering juga merasakan beban tuntutan moril ini (Ismail, 2003). Betapa seharusnya pendeta dan seluruh keluarganya perlu untuk menyerahkan hidupnya dihadapan Tuhan dengan sungguh-sungguh. Hal itu menjadi penting karena seluruh anggota jemaat menjadikan pendeta dan keluarga panutannya.

Dalam pendidikan Kristen peran keteladanan adalah prinsip yang paling penting demi keberhasilan pendidikan. Terlebih untuk para pendeta, bahwa sebagai seorang teladan pendeta hendaknya menampakkan gaya hidup yang sesuai dengan Firman Tuhan. Firman Tuhan yang disampaikan oleh pendeta hendaknya terlebih dahulu mencerminkan kehidupannya (Cahyami, 2020). Sebagaimana Abraham sebagai Bapa orang yang percaya selain Ia mewariskan imannya melalui pengajaran, Ia juga menjadi teladan yang hidup bagi anaknya. Kehidupan seorang ayah yang beriman akan menghasilkan keluarga yang mencerminkan imannya (Robert Richard, 2003).
Lebih lanjut mengenai keteladanan sebagaimana Ulangan 6:7, pendidikan kristen haruslah di lakukan dan diajarkan berulang-ulang. Pengajaran itu melalui ucapan, perbuatan, dan tingkah laku. Kata Ibrani dalam ayat ini adalah "shinnantam" dari kata dasar "shaman" yang berarti mengasah atau menajamkan. Kata ini sebagai gambaran kegiatan yang dilakukan secara berulang-ulang seperti seorang mengasah pisau demi mendapati benda itu semakin tajam. Inilah artinya bahwa dalam rumah tangga seorang bapa dan ibu harus secara terus menerus dari sejak kecil mengajarkan tentang Yesus dalam kehidupan mereka. Bukan saja melalui perkataan melainkan melalui teladan pola hidup yang dilakukan secara terus menerus (Hasudungan Simatupang, 2014). Dalam hal ini anak-anak harus diperlakukan sebagai subyek yang menerima Firman Tuhan dengan berulang-ulang dalam segala waktu dan tempat (Hura \& Mawikere, 2020).

Selain keteladanan, disiplin adalah bagian terpenting dalam pendidikan di tengah keluarga. Jangan sampai karena kasihnya kepada anak-anaknya, maka orang tua meniadakan teguran atau pendisipinan. Justru pendisiplinan sebagai tanda bahwa orang tua mengasihi anak mereka. Tujuan dari mendisiplin ialah mendidik seorang anak untuk menguasai diri mereka sendiri. Mulai dari kecil anak 
iharus sudah diajarkan betapa pentingnya penurutan. Setiap anak harus di tolong agar memandang semua perkara ada di bawah sebuah aturan, dan sehingga jika terjadi pelanggaran itu akan menuntun kehancuran dan kebinasaan. (White, 2010a). Disinilah kita dapat lihat bahwa pendisiplinan harus dilaksanakan dalam keluarga pendeta.

Dari penjelasan masalah di atas maka tujuan penelitian ini adalah untuk mendapatkan deskripsi tentang penerapan disiplin yang benar dan peran keteladanan pendeta terhadap kesetiaan anak-anak pendeta kepada Tuhan di dalam Gereja Masehi Advent Hari Ketujuh (GMAHK) Konfrens DKI Jakarta. dan rumusan masalahnya adalah:

1. Sejauh mana penerapan disiplin yang dilakukan pendeta kepada anak-anak pendeta?

2. Sejauh mana teladan yang telah diberikan orang tua kepada anak-anak pendeta?

3. Sejauh mana penerapan disiplin dan keteladanan memengaruhi kesetiaan anak-anak pendeta?

\section{METODE PENELITIAN}

Penelitian ini menggunakan metode kuantitatif dengan pendekatan deskriptif statistik untuk mengetahui dampak penerapan disiplin yang benar dan peran keteladanan terhadap kesetiaan anak-anak pendeta di usia remaja dan dewasa atau yang memiliki usia di atas 15 tahun. Responden penelitian ini adalah semua anak-anak pendeta yang melayani di Gereja Masehi Advent Hari Ketujuh (GMAHK) Konfrens DKI Jakarta. Sampel penelitian ini adalah 108 responden. Teknik pengambilan sampelnya adalah teknik purposive sampling. Purposive sampling merupakan teknik pengambilan sampel dari sumber data dengan pertimbangan tertentu (Sugiyono, 2009). Analisis data yang digunakan adalah untuk mengetahui bagaimana penerapan disiplin dan peran keteladanan pada anak-anak pendeta.

\section{HASIL DAN PEMBAHASAN}

Berikut ini adalah hasil dari variabel penerapan kedisiplinan dan keteladanan dengan indikator pernyataan seperti pada tabel 1.1.

Tabel 1.1

Hasil Deskriptif Kuesioner secara Persentase

\begin{tabular}{ccccccc}
\hline No & $\begin{array}{c}\text { Variabel Penerapan } \\
\text { Disiplin }\end{array}$ & $\begin{array}{c}\text { Sangat } \\
\text { Tidak } \\
\text { Setuju }\end{array}$ & $\begin{array}{c}\text { Tidak } \\
\text { Setuju }\end{array}$ & Ragu-Ragu & Setuju & $\begin{array}{c}\text { Sangat } \\
\text { Setuju }\end{array}$ \\
\hline 1 & $\begin{array}{l}\text { Disiplin dimulai sejak } \\
\text { dini }\end{array}$ & $0 \%$ & $0 \%$ & $0,9 \%$ & $8,3 \%$ & $90,8 \%$ \\
\hline
\end{tabular}




\begin{tabular}{|c|c|c|c|c|c|c|}
\hline 2 & $\begin{array}{l}\text { Orang tua harus } \\
\text { memiliki pengendalian } \\
\text { diri. }\end{array}$ & $0 \%$ & $0 \%$ & $0 \%$ & $9,8 \%$ & $90,2 \%$ \\
\hline 3 & $\begin{array}{l}\text { Pentingnya ketegasan } \\
\text { dan konsistensi dalam } \\
\text { disiplin. }\end{array}$ & $0 \%$ & $0,9 \%$ & $3,7 \%$ & $23,9 \%$ & $71,6 \%$ \\
\hline 4 & $\begin{array}{l}\text { Memukul anak boleh } \\
\text { dilakukan jika cara lain } \\
\text { telah } \\
\text { memperoleh } \\
\text { kegagalan. }\end{array}$ & $5,5 \%$ & $10,1 \%$ & $31,2 \%$ & $29,4 \%$ & $23,9 \%$ \\
\hline & $\begin{array}{c}\text { Variabel Peran } \\
\text { Keteladanan }\end{array}$ & & & & & \\
\hline 5 & $\begin{array}{l}\text { Orang tua adalah guru } \\
\text { yang pertama }\end{array}$ & $0 \%$ & $0 \%$ & $0 \%$ & $11 \%$ & $89 \%$ \\
\hline 6 & $\begin{array}{l}\text { Pentingnya penyerahan } \\
\text { diri agar } \\
\text { dapat menjadi teladan } \\
\text { yang baik. }\end{array}$ & $0 \%$ & $0 \%$ & $0,9 \%$ & $2,8 \%$ & $96,3 \%$ \\
\hline 7 & $\begin{array}{l}\text { Yesus adalah guru } \\
\text { yang paling sempurna. } \\
\text { Para pendeta adalah } \\
\text { mereka yang lebih } \\
\text { banyak } \\
\text { mengetahui Firman } \\
\text { Tuhan sehingga } \\
\text { dituntut menerapkan } \\
\text { lebih banyak }\end{array}$ & $0 \%$ & $0 \%$ & $0 \%$ & $0,9 \%$ & $99,1 \%$ \\
\hline 8 & $\begin{array}{l}\text { Variabel Kesetian } \\
\text { Seorang Anak Kepada } \\
\text { Tuhan }\end{array}$ & $6,4 \%$ & $10,1 \%$ & $15,6 \%$ & $30,3 \%$ & $37,6 \%$ \\
\hline 9 & $\begin{array}{l}\text { Sejak kecil anak-anak } \\
\text { harus selalu diingatkan } \\
\text { agar } \\
\text { setia kepada Tuhan. }\end{array}$ & $0 \%$ & $0 \%$ & $0 \%$ & $2,8 \%$ & $97,2 \%$ \\
\hline 10 & $\begin{array}{l}\text { Semakin saya } \\
\text { mengenal Tuhan } \\
\text { saya akan semakin } \\
\text { setia kepada Tuhan. }\end{array}$ & $0 \%$ & $0 \%$ & $2,8 \%$ & $16,5 \%$ & $80,7 \%$ \\
\hline 11 & $\begin{array}{l}\text { Setia kepada Tuhan } \\
\text { sejak muda } \\
\text { kemungkinan } \\
\text { besar akan setia kepada } \\
\text { Tuhan sampai tua. }\end{array}$ & $1,8 \%$ & $2,8 \%$ & $12,8 \%$ & $22,9 \%$ & $59,6 \%$ \\
\hline
\end{tabular}

Dari tabel didapati bahwa 90,8\% (99 responden) anak-anak pendeta GMAHK Konfrens DKI Jakarta dan sekitarnya sangat meyetujui adanya penerapan disiplin yang dimulai sejak dini. Penting bagi anak memahami serta memiliki suatu keinginan yang harus dikendalikan (White, 2010a). Pelaksanaan disiplin yang proporsional pada anak akan mempengaruhi bagaimana karakter dan 
masa depan anak (Hendra, 2018). Tentu berbeda penerapan disiplin bagi anak-anak usia remaja dengan mereka yang masih dibawah 8 tahun. Bagi anak-anak di usia 38 tahun pelaksanaan penerapan disiplin lebih ringan dibandingkan anak di usia 8 tahun ke atas. Bagi anak diusia 3-8 tahun penerapan disiplin ditujukan agar anak dapat mengetahui mana yang berbahaya dan mana yang tidak berbahaya (Halim, 2003). Walaupun demikian tetap saja dalam pelaksanaan disiplin harus di mulai pada saat seorang anak mulai memilih kemauan dan jalannya. Jika orang tua tidak mengendalikan keinginan anaknya sejak kecil akan mengakibatkan kebiasaan yang memanjakan yang dapat membawa kepada kecenderungan yang jahat. Itu sebabnya perlu adanya penerapan disiplin sejak dini.

Dalam pernyataan yang lain, bagi para orang tua yang menerapkan pendisiplinan kepada anak mereka, 90,8\% (99 responden) anak-anak pendeta sangat setuju harus ada pengendalian diri orang tua yang menerapkan disiplin kepada anakanaknya. Para orang tua yang mau mengendalikan anaknya harus terlebih dahulu mampu mengendalikan diri mereka sendiri (White, 2010a). Karena pengendalian diri juga adalah implementasi dari kasih orang tua kepada anak mereka. Pertunjukan disiplin tanpa kasih akan menghasilkan disiplin yang tidak bertujuan memperbaiki melainkan hanya memuaskan emosi saja. Emiyati mengatakan bahwa jika sebagai orang tua dalam memberikan pengajaran kepada anak mereka sudah dengan benar, maka mereka tidak perlu memukul atau memperbaiki sebanyak itu. Karena disiplin merupakan sebagian dari karakter yang orang tua tanamkan ke dalam diri anak dan yang akan menentukan cara hidupnya di waktu mendatang (Emiyati, 2018).

Selain itu dalam menunjang kesetiaan anak-anak pendeta kepada Tuhan juga diperlukan penerapan disiplin yang tegas dan konsisten serta penuh kesabaran sebanyak 71,6\%. 78 responden dari anakanak pendeta sangat mendukung pernyataan tersebut. Ketegasan dan kesabaran adalah kunci dari disiplin yang berhasil. Banyak orang tua yang mendapat ejekan karena perlakuan dan penetapan disiplin yang tidak tegas dan konsisten (Hasanah, 2018). Pembahasan lain dari indikator disiplin, didapati bahwa 31,2\% (34 responden) anak-anak pendeta raguragu bahwa pemukulan terhadap anak dapat dilakukan jika cara lain memperoleh kegagalan. Pada zaman sekarang ini pemukulan memang mengalami satu dilema tersendiri bagi dunia pendidikan. Dalam pembahasan ini pemukulan bukanlah cara utama atau satu-satunya melainkan cara yang paling terakhir. Pemukulan harus dilakukan dengan dilandaskan atas kasih dan pengendalian 
diri. Sebagaimana tertulis dalam Amsal 23:14 "Engkau memukulnya dengan rotan, tetapi engkau menyelamatkan nyawanya dari dunia orang mati.”. Jika seorang anak dapat menerima disiplin dengan teguran yang patut maka pemukulan adalah hal yang tidak diperlukan sama sekali (White, 2010a).

Pada indikator peran keteladanan dalam keluarga pendeta, didapati 89\% (97 responden) anak-anak pendeta menyatakan bahwa keteladanan orang tua adalah yang utama dalam menunjang kesetiaan mereka kepada Tuhan, Di dalam rumah tangga anak akan mendengar, melihat, meniru apa yang dilihat pada orang tua mereka. Apa yang mereka lihat dan rasakan diserap yang kemudian menjadi sebuah tindakan. Keteladanan orang tua jauh lebih berpengaruh daripada nasihat-nasihat yang disampaikan (Purba, 2020). Metboki mendukung hal tersebut dengan mengatakan bahwa semua aspek yang berperan dalam pembentukan karakter anak. Orang tua memiliki peranan yang signifikan karena orangtua adalah pendidik utama non formal bagi anak. Sebagai pendidik utama, orangtua dapat memberi dampak yang signifikan bagi perkembangan karakter anak. Sebagai pemberi dampak, tentunya orangtua harus menjadi teladan yang hidup bagi anak-anak dalam perbuatan dan perkataan (Metboki, 2020).
Selain itu indikator lain menyatakan bahwa 96,3\% (105 responden) anak-anak pendeta sangat setuju jika para pendeta dalam mendidik anak-anak mereka harus memiliki penyerahan diri setiap hari kepada Tuhan dengan sungguh-sungguh. Tujuannya agar benar-benar dapat menjadi teladan yang baik bagi anak-anak mereka. Pernyataan dalam kuesioner ini juga menekankan bahwa penyerahan diri secara sepenuhnya kepada Tuhan akan menunjang pola hidup yang berkenan kepada-Nya (Simanjuntak, 2016). Sebagaimana Yesus yang adalah sebagai wujud seratus persen manusia Yesus menunjukan ketergantungan-Nya yang sungguh-sungguh kepada Allah Bapa (Metboki, 2020).

Indikator lainnya menjelaskan bahwa 99,1\% (108 responden) anak-anak pendeta sangat menyetujui bahwa Yesus adalah teladan guru yang paling baik dan sempurna dalam penggajaran-Nya. Ada keselarasan antara pengajaran dan penerapan dalam pola hidup-Nya seharihari. Pola hidup yang sempurna dan kasih yang nyata yang dipraktekkan dalam kehidupan Yesus adalah contoh penerapan yang sempurna dalam dunia pendidikan. Sudah seharusnyalah hanya kepada Yesuslah para orang tua memohon tuntunan dan hikmat agar mampu menjadi teladan yang baik bagi anak-anak mereka (Tafonao, 2018). Siburian mengatakan 
bahwa kemuliaan Yesus sebagai teladan bagi para orang tua dan para guru memiliki 3 hal penting: (1) Otoritas dan kuasa pengajaran-Nya yang sangat kuat. (2) Memiliki tujuan yang mulia untuk mengubah kehidupan para pengikut-Nya menjadi pribadi yang lebih baik (walaupun dari latar belakang berbeda). (3) Yesus disertai dengan visi Kerajaan Allah yang rohani dan seutuhnya dalam menyelamatkan manusia yang berdosa (Siburian, 2018).

Indikator yang rendah adalah tentang para pendeta adalah mereka yang lebih banyak mengetahui Firman Tuhan sehingga dituntut menerapkan lebih banyak dibandingkan anggota awam mendapatkan nilai terendah, 15,6\% (17 responden) ragu-ragu dan $10,1 \% \quad$ (11 responden) tidak setuju dengan pernyataan tersebut. Membahas mengenai penurutan seharusnya semua umat-umat Tuhan dituntut menerapkan perintah Tuhan yang tertulis dalam Firman-Nya. Tetapi tidak dapat dipungkiri bahwa ketidakmenurutan pendeta dapat mengakibatkan dampak yang besar bagi keluarga dan juga anggotaanggota jemaat tapi keteladanan pendeta akan membimbing anggota jemaatnya kepada pengajaran yang benar (Deriver, n.d.)

Sebagaimana imam Eli yang memiliki pengaruh yang luas sebenarnya dia hanyalah sebagai manusia biasa.
Kehidupan keluarganya sebagai seorang imam dan hakim dicontoh oleh seluruh bangsa Israel. Alasannya adalah karena betapapun besarnya kejahatan-kejahatan di dalam keluarga, itu akan menjadi sepuluh kali lipat lebih besar bilamana itu terjadi di dalam keluarga-keluarga yang telah ditetapkan sebagai guru orang banyak (White, 2011).

Masuk ke dalam pembahasan mengenai kesetiaan anak pendeta kepada Tuhan, sebenarnya mayoritas anak-anak pendeta megetahui bahwa kesetiaan kepada Tuhan harus dimulai sedini mungkin. 97,2\% (106 responden) anakanak pendeta sangat menyetujui bahwa kesetiaan kepada Tuhan harus dibiasakan sejak kecil. Kesetiaan itu tidak timbul tibatiba melainkan melalui proses perjalanan kerohanian yang dibiasakan. Sejak kecil anak-anak harus diajarkan setia kepada Tuhan. Dalam perkara apapun Tuhan rindu orang-orang muda menyerahkan hati mereka kepada Tuhan setiap hari (White, 2010a). Selain itu dalam pembahasan ini, 80,7\% (88 responden) anak-anak pendeta GMAHK Konfrens DKI Jakarta dan sekitarnya juga meyakini bahwa semakin seorang anak diperkenalkan kepada Tuhan sejak kecil maka anak itu akan semakin setia kepada Tuhan ketika dia tumbuh dewasa. Jika sejak muda sudah mengenal Tuhan, maka mereka diharapkan selalu setia dan taat bahkan juga menjadi terang 
kepada sesama manusia disekitarnya saat mereka bertumbuh dewasa (Chia et al., 2020).

Indikator pernyataan kesetiaan yang dimulai sejak kecil kemungkinan besar akan setia kepada Tuhan sampai tua mendapatkan nilai yang terendah, 12,8\% (14 responden) anak-anak pendeta raguragu dengan pernyataan tersebut. Sesungguhnya tidak dapat dipastikan jika seseorang setia kepada Tuhan waktu kecil akan menjadi umat Tuhan yang setia pula hingga dia dewasa. Tetapi yang dapat menguatkan argumentasi ini adalah kebiasaan-kebiasaan yang baik yang dimulai sejak dini akan membuat kecenderungan-kecenderungan jahat pada waktu dewasa akan semakin berkurang. Dalam hal ini sebagai orang tua penting untuk melakukan pencegahan dengan menanamkan nilai kesetiaan yang benar sejak kecil agar ketika dewasa anak itu akan mengingat perkara tersebut. Proses pengenalan dengan Allah harus selalu terjadi setiap hari, melalui pembacaan Alkitab, meditasi, doa pribadi, peribadatan, dan pelayanan di dalam gereja. Orangorang muda harus memulainya sedini mungkin. Ini akan membangun kesetiaan kita kepada Tuhan sampai mereka tua (Riggs, 1996). Sebagai orang muda tidak boleh mereka percaya bahwa mereka tidak bisa mengatasi kedagingan mereka dan bahkan karena hal tersebut mereka percaya seharusnya mereka membiarkan kedagingan mereka melakukan apa saja yang didambakannya. Ini adalah pelanggaran hukum yang mengerikan. Kaum beriman orang-orang muda harus memperhatikan untuk menjauhkan nafsu orang muda (Lee, 2020b).

\section{Disiplin dan Pelaksanaannya}

Disiplin harus di mulai pada waktu seorang anak mulai memilih keinginannya sendiri. Hal inilah penting untuk dikendalikan karena terkadang tanpa disadari para orag tua selalu memberikan apa yang diinginkan oleh anak mereka. Oleh karena itu bayi sekalipun pada saat menunjukan suatu keinginan yang keras jika itu tidak di kendalikan ke dalam suatu wewenang yang bijaksana, maka iblis akan menguasai hati, pikirannya dan menimbulkan kecenderungan yang jahat. Para orang tua memberikan pelajaran pertama mengenai disiplin pada saat anakanak masih bayi. Pada masa ini tidak boleh melakukan tindakan pengajaran dan disiplin yang keras, tetapi anak-anak harus di ajarkan menyerahkan kehendak mereka kepada kehendak orang tua. Kegiatan ini harus dilakukan dengan penuh kasih disaat yang sama tetap menunjukan sikap yang tegas. Imam Eli sebagai seorang pemimpin di tengah-tengah keluarga tidak menunjukan sikap tegas dan konsisten dalam mendisiplin anaknya sejak dini. 
Sebagai seorang ayah ia membiarkan pelanggaran anak-anaknya sejak kecil, sambil berharap bahwa pada suatu waktu mereka akan dengan sendirinya menyadari kesalahan mereka. Akibat dari pemanjaan inilah akhirnya timbul kecenderungankecenderungan mereka yang jahat (White, 2010a). Pendidikan anak usia dini (PAUD) adalah sesuatu yang sangat penting, ini adalah suatu upaya pembimbingan anak sejak lahir hingga usia 6 tahun. Ini adalah usaha pembentukan perkembangan anak secara jasmani dan rohani agar anak itu dipersiapkan menerima pendidikan yang lebih lanjut. Salah satu pengembangan moral yang haru ditanamkan pada anak sejak dini adalah disiplin (Martsiswati \& Suryono, 2014).

\section{Pelaksanaan Disiplin yang Bersifat Memperbaiki}

Dalam memberikan pengajaran dan disiplin para orang tua harus meminta masuk dan memerintah dalam hati mereka. Sementatara orang tua melakukan tugas yang berat dan penuh tanggungjawab, Tuhan harus diutamakan dalam doa bersama dengan anak-anak. Roh Kudus akan datang untuk mengingatkan dan menginsafkan manusia dari dosa dan kesalahan jika manusia tersebut datang dan meminta Roh itu untuk memerintah di hati mereka (Yohanes16:8).

Dalam mengajar, orang tua harus melakukannya dengan sabar. Tuhan mengkhendaki para orang tua melakukannya berulang-ulang (Ulangan 6:7), Dalam disiplin yang penuh kesabaran dan konsisten di harapkan akan ada perubahan yang lebih baik. Dalam meberikan disiplin untuk memperbaiki seorang anak, tidak boleh dengan amarah tanpa adanya pengendalian diri. Kata-kata yang kasar disertai dengan kemarahan yang meluap tidak membuat anak menjadi lebih baik. Bagi orang tua yang ingin mengendalikan anak-anak mereka, harus terlebih dahulu dapat mengendalikan diri mereka sendiri. Bagi para orang tua dalam memberikan disiplin harus memberikan sedikit perintah, dan harus dipastikan perintah itu ditaati. Di dalam peritah itu juga harus ditanamkan tujuan untuk mendapatkan kebajikan tertinggi bagi pertumbuhan mereka sebagai anak-anak.

Dalam pendidikan di tengah keluarga memukul anak bisa jadi diperlukan jika saja cara lain gagal, walaupun begitu jika hal tersebut masih bisa dihindari maka janganlah orang tua melakukan hal tersebut. Namun jika cara yang lembut ternyata tidak cukup, sehingga hukuman yang membawa anak itu kepada hikmat dan pengertian tetap harus dilakukan atas dasar kasih sayang. Orang tua akan mendapati bahwa kalau saja mereka bertukar pikiran dengan anak-anak dipenuhi dengan hikmat, maka anak-anak itu tidak perlu di pukul (White, 2010a). 
Oleh karena itu kalaupun disiplin berupa hukman fisik diperlukan itu adalah cara paling terakhir, dan sekali-kali jangan lakukan diseratai dengan kemarahan melainkan dengan kasih. Orang tua harus lebih dulu menggunakan pertimbangan yang matang dan doa yang sungguhsungguh. Fokus disiplin itu sendiri adalah peraturan. Peraturan yang paling efektif kepada anak-anak adalah aturan yangmudah dipahami, diingat dan diterima. Perilaku kebiasaan diterapkan pola tertentu yang mengatur perilaku anak dalam proses pembelajaran. (Martsiswati \& Suryono, 2014).

\section{Dengan Kasih dan Ketegasan}

Kebaikan hati harus menjadi dasar di dalam rumah tangga, tetapi kebaikan hati yang dimaksudkan bukan kebaikan hati yang menuntun kepada pemanjaan melainkan kebaikan hati yang menuntun kepada pertumbuhan tabiat anak. Efesus 6:4 menjelaskan kepada para orang tua aagar tidak membangkitkan amarah di dalam hati anak-anak mereka, nasihat ini adalah suatu nasihat Tuhan kepada para orang tua khususnya untuk para ayah. Orang-orang tua harus memahami bahwa anak-anak mereka masih muda dan belum berpengalaman di dalam usia. Oleh karena itu dalam mengendalikan dan mendisiplin mereka, harus tegas, namun tetap dengan lemah lembut dan kasih sayang. Para orang tua harus memahami bahwa kekerasan menumbuhkan roh melawan. Kekejaman atau hukuman yang tidak didasari dengan kasih tidak akan membawa anak-anak untuk melaksanakan prinsip yang benar. Dalam melaksanakan tugas yang penting ini harus pertahankan ketegasan yang seragam, dan pengendalian diri (White, 2010a). Wewenang dalam rumah tangga harus disokong dengan ketegasan, kalau tidak, maka hal itu akan menjadi ejekan dan cemoohan. Orang tua harus selalu mempertimbangkan cara tepat dalam melaksanakan disiplin untuk anak sejak mereka balita sampai usia mereka remaja. Dalam hal ini disiplin bertujuan untuk mengarahkan anak supaya mereka mampu memilih hal-hal baik sejak dini yang akan menjadi persiapan bagi mereka untuk masa yang akan datang. Orangtua yang benarbenar menyadari bahwa ada waktu yang tepat bagi mereka untuk menunjukan sikap tegas dalam memberikan batasan agar rasa percaya diri yang benar bisa tumbuh dalam diri anak-anak mereka (Hasanah, 2018).

\section{Yesus Guru Teladan}

Sebagai orang Kristiani harus menjadikan Yesus sebagai teladan, begitu juga ketika kita berperan guru di tengah keluarga. Berdasarkan teladan yang diterapkan oleh Yesus Kristus, Alkitab menceritakan dengan jelas bahwa Yesus benar-benar adalah seorang Guru yang 
menerapkan peranan-Nya dengan sempurna ditengah-tengah pengikutpengikut-Nya. Yesus datang ke dunia menunjukan pribadi Allah melalui kegiatan mengajar, berkhotbah, mengadakan mukjizat dan mendemontrasikan teladan hidup yang sempurna. Ia mengajar melalui tindakan nyata dan kata-kata yang berkuasa serta tanda-tanda ajaib. Yesus tidak seperti guru-guru pada umumnya pada saat itu dalam hal mengajar. Yesus menunjukkan kasih yang besar kepada mereka, bahkan Yesus sangat memberikan perhatiannya kepada anak kecil yang jarang mendapat perhatian. Kenapa pengajaran Yesus begitu berkuasa?, hal tersebut di karenakan apa yang Yesus katakan di dukung dengan apa yang Yesus hidupkan (Tafonao, 2018). Yesus sebagai teladan para orang tua menunjukan kasih pengorbanan yang sangat besar, ini artinya sikap egoisme adalah sikap yang harus dijauhkan dari orang tua, karena mereka harus menyadari bahwa ada tanggung jawab besar bagi mereka untuk mendidik anak-anak mereka.

Yesus sebagai teladan yang Agung bagi para orang tua memperlihatkan keselarasan dari apa yang Ia sampaikan dalam pengajaran-Nya dengan apa yang Ia praktekan dalam kehidupan-Nya. Sebagai wujud seratus persen manusia Yesus menunjukan ketergantungan-Nya yang sungguh-sungguh kepada Allah Bapa. Benar bahwa para orang tua tidak ada yang sempurna bahkan pendeta sekalipun, oleh karena itu butuh ketergantungan yang sepenuhnya dan penyerahan diri setiap hari kepada Bapa di Sorga agar para orang tua mampu melakukan kehendak-Nya (Simanjuntak, 2016). Yesus bersifat sangat kritikal terhadap para Ahli Taurat dan orang Farisi ,sebab walaupun mereka sangat menguasai Hukum Taurat bahkan sampai sangat teliti, namun mereka tidak melakukan atau mengimplementasikan apa yang mereka ajarkan dalam hidup mereka sendiri (Hartoyo, 2016).

Sebagai pendeta pelajaran dari para Ahli Taurat ini sangat penting untuk diperhatikan. Pendeta pasti mempelajari dan mengetahui Firman Tuhan dalam kehidupan mereka, dan tentu juga mengajarkannya kepada anggota-anggota jemaat. Oleh karena itu harus ada tanggung jawab tersendiri untuk menerapkan itu semua di dalam hidup mereka. Pola hidup seseorang sangat berpengaruh daripada ucapan-ucapannya. Konsep ini menjadikan teladan hidup sebagai hal yang paling penting dibandingkan dengan nasihat atau teori yang terlalu banyak. Peran keteladanan mempunyai nilai yang sangat relevan jika dibandingkan dengan berbagai ucapan dan ekspresi lahiriah lainnya. Salah satu teladan Tuhan Yesus yang membuat murid-muridNya tersentuh hatinya adalah teladan Tuhan Yesus saat membasuh kaki murid-muridNya dalam Yohanes 13:1-17 
yang sebenaranya hendak mengajaran tentang kasih, merendahkan diri, rela berkorban, dan saling melayani (Sunarko, 2020).

\section{Keteladanan Orang Tua yang Utama}

Dalam sebuah pendidikan yang benar, keteladanan orang tua adalah yang utama. Pendidikan anak yang pertama berasal dari orang tua. Anak akan mendengar, melihat, meniru apa yang dilihat pada orang tua mereka. Apa yang mereka lihat dan rasakan diserap yang kemudian menjadi sebuah tindakan. Keteladanan orang tua jauh lebih berpengaruh daripada nasihat-nasihat yang disampaikan (Purba, 2020). Seseorang yang paling dekat dan mengetahui setiap perkembangan seorang anak seharusnya adalah orang tuanya. Jangan biarkan anakanak melihat contoh atau teladan dari luar rumah ataupun dari tontonan-tontonan yang membuat mereka jauh dari pada Tuhan. Para orang tua harus menggali sedalam-dalamnya segala sesuatu yang dapat diberikan oleh iman Kristen mereka untuk di wariskan kepada anak-anak mereka. Suatu kebiasaan peribadatan dan merenungkan Alkitab setiap hari serta berdoa bersama-sama dengan seluruh anggota keluarga. Itu akan dengan sendirinyamenjadi suatu pengingat kepada anak-anak untuk menjadikan kebiasaan persekutuan dengan Tuhan sebagai pola hidup sepanjang hidup mereka (Leigh, 2007).

\section{Kesetiaan Kepada Tuhan Harus \\ Dimulai Sejak Dini.}

Sejak kecil anak-anak harus diajarkan setia kepada Tuhan. Dalam perkara apapun Tuhan rindu orang-orang muda menyerahkan hati mereka kepada Tuhan setiap hari (White, 2010b). Ketaatan kepada orang tua akan menuntun anakanak untuk menunujukkan kataatan mereka kepada Tuhan, ketika anak-anak menunjukan sikap hormat kepada orang tua mereka akan belajar bagaimana menunjukan rasa hormat kepada Bapa yang ada di surga. Sebagaimana tertulis dalam Lukas 16:10 bahwa jika seseorang menunujukkan kesetiaannya dalam perkara-perkara kecil, ia juga akan setia dalam perkara-perkara yang besar dan apabila mereka tidak setia dalam perkaraperkara kecil, ia juga tidak akan setia juga dalam perkara-perkara besar. Prinsip kesetiaan inilah yang perlu ditanamkan sejak kecil kepada anak-anak. Setiap tugas dan tanggung jawab harus dilakukan dengan setia, terutama tugas dalam pelayanan kepada Tuhan. Inilah yang juga di harapkan kepada orang-orang muda lakukan sehingga akan membentuk pribadi mereka yang suka melayani dan takut akan Tuhan (Lee, 2020a). Jika sejak muda sudah mengenal Tuhan, maka mereka diharapkan 
selalu setia dan taat bahkan juga menjadi terang, menjadi teladan bagi orang-orang muda lainnya (Chia et al., 2020).

\section{KESIMPULAN}

Melalui penelitian yang telah dilakukan, didapati beberapa kesimpulan yang diperoleh oleh peneliti: Adanya permasalahan kesetiaan anak-anak pendeta kepada Tuhan disebabkan kurangnya penerapan disiplin yang benar dan kurangnya peran keteladanan orang tua kepada anak-anak mereka, oleh karena itu dari penelitian ini peneliti menyimpulkan bahwa untuk menunjang kesetiaan anakanak pendeta kepada Tuhan perlu adanya penerapan disiplin yang benar yang dimulai sejak dini, yaitu penerapan disiplin yang tegas, konsisten serta penuh kasih dan kesabaran. Selain itu dalam penerapan disiplin juga diperlukan pengendalian diri bagi para orang tua, agar tujuan dari disiplin itu benar-benar untuk memperbaiki bukan hanya untuk meluapkan emosi belaka. Selain penerapan disiplin yang benar, salah satu penunjang kesetiaan dari para anak-anak pendeta adalah peran keteladanan dari pendeta itu sendiri. Didapati para anak-anak pendeta melihat ketidaksesuaian antara apa yang dikatakan dengan apa yang dilakukan oleh orang tua mereka. Oleh karena itu sebagai contoh hidup keteladanan yang paling sempurna dapat dilihat dari pola hidup Yesus, dimana dalam Alkitab Yesus menunjukan keselarasan yang sempurna antara pengajaran dan praktek kasih yang dihidupkan, oleh karena itu untuk para pendeta agar dapat menghidupkan kehidupan keteladanan yang baik perlu penyerahan hidup yang sungguh-sungguh setiap hari kepada Tuhan. Mengenai kesetiaan kepada Tuhan itu harus dimulai dari sejak dini, itulah sebabnya peran keteladanan dan penerapan disiplin yang benar juga harus dimulai sejak dini, anakanak tidak dibiarkan tanpa disiplin dan contoh hidup yang benar walaupun mereka masih kecil. Selain itu kebiasaan-kebisaan menyembah Tuhan sejak kecil juga akan mengurangi kecenderungan jahat ketika tumbuh dewasa. Sebagaimana Menurut Hutagalung dan Ferinia agar keluargakeluarga Kristen mengimplementasikan suatu tindakan kerohanian dengan sungguh-sungguh. Berdoa khusus, kebaktian pagi dan petang, membaca Alkitab secara teratur harus diterapkan dengan disiplin hal inilah yang akan menunjang kesetiaan anak-anak kepada Tuhan (Hutagalung \& Ferinia, 2020). Melihat hal tersebut penulis menyimpulkan bahwa peran para pendeta dalam mendisiplin anak mereka sejak dini dan menunjukan teladan pola hidup yang benar dihadapan anak-anak mereka akan mempengaruhi meningkatnya kesetiaan anak-anak pendeta kepada Tuhan. 
Melalui hasil penelitian, pembahasan dan kesimpulan yang didapatkan oleh peneliti selama pelaksanaan penelitian, maka peneliti memberikan saran yang diharapkan mampu memberikan manfaat, yaitu: untuk penerapan disiplin yang benar perlu adanya ketegasan tanpa kekejaman, emosi yang tidak terkendali akan membawa dampak buruk bagi anak. Akan tetapi hukuman fisik juga perlu dilakukan jika cara lain memeroleh kegagalan. Hukuman fisik yang dimaksud adalah disiplin yang didasari oleh kasih demi untuk memperbaiki anak tersebut. Selain itu peneliti juga memberikan saran untuk para pendeta bahwa harus adanya praktek hidup atau teladan yang baik di hadapan keluarga dan umat karena tidak bisa dipungkiri jika pendeta menerapkan kehidupan yang buruk akan berdampak kepada keluarga dan kepada umat-umat Tuhan. Besar harapan jika anak-anak pendeta memliki kerohanian yang baik sejak kecil maka akan berdampak besar sampai anak itu tumbuh dewasa.

\section{DAFTAR PUSTAKA}

Borrong, R. P. (2015). Signifikansi kode etik pendeta. Gema Teologi, 39(1), 73-96.

Cahyami, R. (2020). Implementasi Gaya Hidup Materialisme Pendeta Masa Kini dan Pengaruhnya Terhadap Kualitas Pelayanan. https://doi.org/10.31219/osf.io/n2hz m Diakses tanggal 15 Oktober 2020 Chen, M. (2015). Dilema Anak Hamba Tuhan. Euangelion. https://meilaniachen.weebly.com/me ngasuh-anak/article-10-dilema-anakhamba-tuhan. Diakses tanggal 15 Oktober 2020.

Chia, P. S., Th, M., Sulastri, E., \& Th, M. (2020). Kesetiaan Allah Tak Terkekang Oleh Manusia: Kitab Yunus Bagian 1 (Yunus 1: 1-16). Stiletto Book.

Deriver, J. (n.d.). Pertumbuhan Kerohanian Gereja Masehi Advent Hari Ketujuh Jemaat Immanuel , Batujajar Konfrens Jawa Barat Berdasarkan 1 Petrus 4 : 11.45-70.

Emiyati, A. (2018). Mendisiplin Anak Menurut Prinsip Kristen. Evangelikal: Jurnal Teologi Injili Dan Pembinaan Warga Jemaat, 2(2), 147-156.

Halim, M. (2003). Model-model penginjilan Yesus: suatu penerapan masa kini. Penerbit Gandum Mas.

Hartoyo, S. (2016). Yesus: Tuhan, Guru dan Teladan Orang Percaya. Sanctum Domine: Jurnal Teologi, 4(1), 1-9.

Hasanah, U. (2018). Metode Pengembangan Moral Dan Disiplin Bagi Anak Usia Dini. Martabat, 2(1), 91-116.

Hasudungan Simatupang, M. P. (2014). Definisi Theologi Praktis Kristen. 
Penerbit Andi.

Hendra, V. (2018). Peran Orang Tua Dalam Menerapkan Kasih Dan Disiplin Kepada Anak Usia 2-6 Tahun Sebagai Upaya Pembentukkan Karakter. KURIOS (Jurnal Teologi Dan Pendidikan Agama Kristen), $3(1), 48-65$.

Hura, S., \& Mawikere, M. C. S. (2020). Kajian Biblika Mengenai Pendidikan Anak Dan Hakikat Pendidikan Anak Usia Dini. EDULEAD: Journal of Christian Education and Leadership, 1(1), 15-33.

Hutagalung, S., \& Ferinia, R. (2020). Menjelajahi Spiritualitas Milenial: Apakah Membaca Alkitab, Berdoa, dan Menghormati Acara di Gereja Menurun? JURNAL TERUNA BHAKTI, 2(2), 97-111.

Ismail, A. (2003). Mulai dari Musa dan segala nabi (cetakan ke-3). Jakarta: BPK Gunung Mulia.

Lee, W. (2020a). Sejarah dan Wahyu Jilid 1. Yayasan Perpustakaan Injil Indonesia.

Lee, W. (2020b). Unsur-unsur penting Ekonomi Allah. Yayasan Perpustakaan Injil Indonesia.

Leigh, R. W. (2007). Melayani dengan efektif. BPK Gunung Mulia.

Martsiswati, E., \& Suryono, Y. (2014). Peran Orang Tua dan Pendidik dalam Menerapkan Perilaku Disiplin terhadap Anak Usia Dini. JPPM (Jurnal Pendidikan Dan Pemberdayaan Masyarakat), 1(2), 187-198.

Metboki, R. J. A. (2020). Peranan Orangtua Kristen Dalam Membentuk Karakter Anak. SESAWI: Jurnal Teologi Dan Pendidikan Kristen, 1(2), 55-63.

Murrel, S. (2019). The Problem with Preacher's Kids. https://www.stevemurrell.com/theproblem-with-preachers-kids-2/. Diakses tanggal 14 Oktober 2020. Oliver, E. (2017). Nurturing The Faith of Pastors' Kids: Reflections on A Pastoral Family Stress Study. https://www.ministrymagazine.org/ar chive/2017/05/Nurturing. Diakses tanggal 15 Oktober 2020.

Purba, A. (2020). Tanggung Jawab Orang Tua Kristen Dalam Mendidikan Anak Menyikapi Pandemi Covid-19. EPIGRAPHE: Jurnal Teologi Dan Pelayanan Kristiani, 4(1), 86-97.

Riggs, R. M. (1996). Gembala Sidang yang Berhasil. Malang: Penerbit Gandum Mas, Tt.

Robert Richard, B. (2003). Sejarah perkembangan pikiran dan praktek pendidikan agama Kristen: Dari Yohanes Amos Cornicus Sampai Perkembangan PAK di Indonesia. Gunung Mulia.

Siburian, T. (2018). Perspektif Kristologis 
mengenai "Yesus Guru Agung."

Jurnal Teologi Stulos, 16(2), 179206.

Simamora, M., \& Panjaitan, F. (2018). Lex

Talionis (M. Lumingkewas (ed.)).

Diandra.

Simanjuntak, R. (2016). Dampak Keteladanan Yesus sebagai Guru Agung bagi Guru Pendidikan Agama Kristen Masa Kini. Sanctum Domine: Jurnal Teologi, 4(2), 29-40.

Soesilo, Y. (2014). Keluarga Eli Dalam 1 Samuel 2: 11-36: Suatu Evaluasi Pendidikan Kristen Dalam Keluarga Hamba Tuhan. Jurnal Antusias, 3(5), 136-146.

Soetopo, E. R. (2015). Pergumulan Identitas dan Spiritualitas Anak Hamba Tuhan. STT Seminari Alkitab Asia Tenggara. http://repository.seabs.ac.id/handle/1 23456789/388. Diakses tanggal 15 Oktober 2020.

Sugiyono, M. P. P., \& Kuantitatif, P. (2009). Kualitatif, dan R\&D, Bandung: Alfabeta. Cet. VII.

Sunarko, A. S. (2020). Implikasi Keteladanan Yesus sebagai Pengajar bagi Pendidikan Kristen yang Efektif di Masa Kini. REGULA FIDEI: Jurnal Pendidikan Agama Kristen, 5(2), 118-131.

Tafonao, T. (2018). Peran Gembala Sidang Dalam Mengajar Dan Memotivasi
Untuk Melayani Terhadap Pertumbuhan Rohani Pemuda. Evangelikal: Jurnal Teologi Injili Dan Pembinaan Warga Jemaat, 2(1), 36-49.

White, E. G. (2010a). Membina Anak yang Bertanggung Jawab (E. Takasanakeng (ed.)). Indonesia Publishing House.

White, E. G. (2010b). Membina Keluarga Bahagia (J. . Manullang (ed.)). Indonesia Publishing House.

White, E. G. (2011). Sejarah Para Nabi Jilid 1 (W. Nadeak (ed.)). Indonesia Publishing House. 